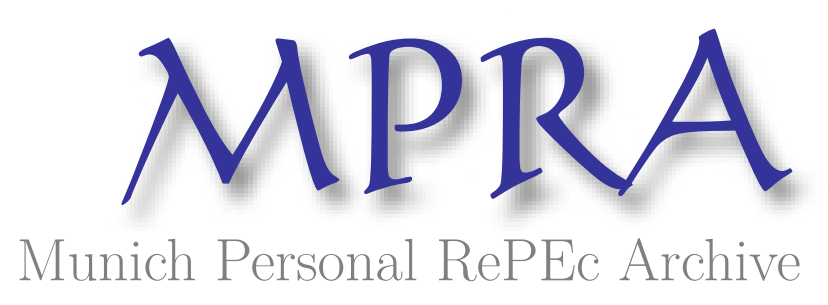

\title{
Discussion of Financial Integration at the Global Market Era
}

\author{
Tursoy, Turgut and Berk, Niyazi
}

Near East University, Bahcesehir University

5 May 2020

Online at https://mpra.ub.uni-muenchen.de/100115/

MPRA Paper No. 100115, posted 05 May 2020 15:43 UTC 


\title{
Discussion of Financial Integration at the Global Market Era
}

\author{
Turgut Tursoy \\ Department of Banking and Finance, Near East University, Nicosia, 99138, \\ North Cyprus, Mersin 10 - Turkey.
}

\section{Niyazi Berk}

Faculty of Business and Economics, Bahcesehir University, İstanbul, Turkey.

\begin{abstract}
This paper purpose is to discuss the latest troubling episode and remind the most critical event again at the world is the integration. First, the last attempt by the countries had been discussing and pronoun that the free market and its extensions are the most prominent phenomena around the world that market participants' perceptions are determined the equilibria prices freely. All the development into the markets witnesses that free market dynamics and the creation of the single global market is the most dominant factor to create a tremendous stimulus behind economic growth. This paper consequently supporting the view that financial integration is providing the necessary conditions to risk-sharing and capital flows to stimulus the economic growth with the expected level at global.
\end{abstract}




\section{Introduction}

The Globalizations attempts are started with the freeing the financial markets at the beginning of the 1980s. Most countries began to liberalise their financial markets and start to integrate the economies to construct a global market. All the necessary attempts are connected with the development of countries to increase the sharing of prosperities each other. Although just not the financial liberalisation is enough to create the necessity of prosperity, but these attempts have created the incentives to integrate all countries with financial markets and the economies. The efforts with the liberalisation started to freeing with removing the ceilings from the prices such as interest rates and Exchange rates. The roofs were being adopted to the interest rates to control the markets from the monetary authorities. With the deregulations, most of the countries started to remove the restrictions on the interest rates to pass through the market Dynamics. Also, with the floating exchange rate system, most of the developed countries accepted the new development into the exchange rate markets. All these changes around four decades ago engaged to the free market dynamics and finding the equilibria for the prices. With this discussion, we would try to show the global changes into the international trade and monetary components into the world.

\section{Free Market Dynamics}

The market Dynamics is here the supply and demand mechanism to determine the prices with the market perceptions and their decisions. This is called in the literature as a "Free Market Dynamics" and its already started with the deregulations. McCauley (2000) stated that economists assume the prices, dynamics, and the market equilibria are supported to be driven from the utility. His results are supposed to represent the stabilising action of Adam Smith's invisible hand mathematically. Rothschild (1994) 
explain Adam Smith's usage of the words of the invisible hand with the three sources. All the necessary documents are reviewed by the Rothschild's work and pronoun that Smiths' use these words with the three resources.

The last one used in The Wealth of Nations' chapter, which is published in the year of 1776. In this chapter concerned international trade. Rothschild explains more about this chapter and state that Smith strongly against the restrictions on the trade (imports). The free market dynamics are started to use with Adam Smith, and he strongly argued that this kind of market would be accessible in the $20^{\text {th }}$ Century. Already the same years, the world started to liberalise their economy and removing the restriction on the necessary prices to pass the free-market economies. Of course, all the years passing through till today first important economic events is the global trade. Every attempt by governments to improve the conditions at the national level is to increase the level of production and later to sell them throughout the world with the new world order. All these amendments taken by the governments to remove the restrictions are to improve the economic conditions have more products in the manner of the economy of scale. When the economies are expanded with more products, they will have more prosperity. Of course, the choice of the consumers is always supporting the new research and development and using the latest product, although it can be done by international trade. Krugman (1994) explained that the new trade theory is an approach to international trade that emphasises precisely the features of the international economy that traditional theory leaves out. Krugman connects the traditional trade with the subjects of increasing returns and imperfect competition. The global markets are improving the competition at the international level and supporting the new paradigms related to research and development. The economy of 
scale is giving the chance to improve the price level of the products to eliminate the enormous prices and let the consumers are using it at low prices.

The discussion is here to find the equilibria with the best utility for the consumers. Although, previously, the theory discuss the abnormal returns of efficient markets. Fama (1991) state that any given time, for example, security prices fully reflect all available information. Therefore there are no abnormal returns from prices when all the market participants have the avail information. The best utility profound from the best decision from the causation of an event. The participants deciding the best price with their preferences with the free market dynamics and all the available market prices represent the best utility of wealth. All participants using the private and publicly available information to shifting their demand and supply to find the equilibria for their wealth. However, some times that the financial markets are not working in the normal rutin, for example, the turmoil times, Malkiel (2011) provides an argument that the security prices do not provide the necessary information regarding the utility.

The essential point here is already discussion that all the country is mostly accepting the free market dynamics to find the prices depending on supply and demand. All-time assuming that the economy and the market pass through with the well-functioning phrase is not rational, but the concern is all time having the well functioning financial markets to determine the equilibria prices.

Eichengreen et al. (1998) connect the financial market integrity and the policy implication with the past experiences with turmoil episodes; the regulations of collective investment vehicles can be grounded in three phrases: consumer protection, systemic risk, and market integrity. The discussion is here, of course, all the regulatory authorities try to protect the customers and alleviate the effects of systemic risk occurrence. The first is already tremendous impact all the investors into the market 
place because the investment activity is the elevating the production level higher into the economy. Therefore, as a regulatory authority, they should provide legal ground into the market to protect all kind of investor into the financial market. Already not all the residential investors also the international investors should be grounded. This is providing a legal environment that all the investors' wealth with together all their returns protected and return back to the origin. The systemic or systematic risk into the local and international market should be alleviated from the supranational institutions like IMF. Lim et al. (2011) study provide the most comprehensive pieces of evidence of the effectiveness of macroprudential policy instruments. They found that macroprudential instruments are effective in reducing pro-cyclicality, and the effectiveness is sensitive to the type of shock facing the financial sector. The macroprudential policies that are serv by the supranational institutions are most likely to be adequate to reduce the systematic risk. All these also discuss with the study of Scott (2010), which explain to reduce the systematic risk in the U.S. of the financial system. All the points are serving the prudential regulation should alleviate the market with the trustable regulation and protecting the customer. Systematic risk is related to the countries itself fundamentals and the international financial markets.

These days, we are experiencing a pandemic all around the world, and this contagion affected all the countries tremendously bad. This exactly is systematic risk and the regulatory authorities such as FED, ECB, Bank of England and the other countries authorities such as Turkey announced new programs with financial support to eliminate the devastating effect of the crises. For example, at March 16, 2020, the Federal Reserve took a series of action to improve up the American economy, with began buying up a type of debt that companies issue for short-term cash and then establish a program to help banks at the core of the financial system function smoothly. 
Also, the Fed cut the interest rates into the financial system to eliminate the pressure on the investors. The US Fed has cut interest rates by 0.5 per cent points to support households and business through the worst of the virus epidemic. The Bank of England took action for increasing the bank lending with a 0.5 percentage point cut in the bank's base interest rate. Despite the market expectations for a reduction, The ECB did not cut the interest rates. However, the central bank did announce measures to support bank lending and expanded its asset purchase by 120 billion euros ( $\$ 135.28$ billion). Also two day later, Turkey announced a $\$ 15.5$ billion stimulus program to ease the financial burden on the business and individuals affected by the pandemic.

All the programs is an example for a systematic risk occurrence into the economy and all the individuals, households, institutions and businesess affected by this risk. With the above example we can summurised that the governments and the authorities progress with an common action to solve the risk with the programs. All the investors should be protected to have a well-funtioning markets to continuous with the everyday routine.

Market integrity and regulations are discuss into the literature , for instance, Spatt (2009) emphasized the regulations related to financial stability which is focus on traditional prudential supervision and another one with safety and soundness of financial system as a whole with fair roles of conduct. These are essential to help the markets to recognize the underlying market failures and respond them with the necessary regulations.

Austin (2016) stated that one of the main purposes of the regulations into the financial markets into the world is to protect the integrity or fairness of the markets. Austin (2016) provide the components as protecting investors, improving the efficiency of 
markets, and protecting the markets from systemic risk, which is the four fundamentals goals of regulations.

\section{Financial Integration}

Although many years the world economy is troubling by the unstable episode over the years, but the tremendous phenomena are the globalisation. To remove the restrictions behind the trade and flows over the countries is the most essential project to create the global economy. For instance, European union is the most common example to remove all the restriction on mobilising the financial and human capitals among to the member state to create the necessary prosperity to create the common wealth to stimulus the conditions. All the attempt are started first to harmonise the regulation among the member countries and after integrating based on financial and economical to create a single market. Of course, not just the integration is happening also Europe create a new currency which is Euro and most of the member of the country using the Eoru as a primary currency in their everyday life. Also not in Europe, in the world also create the necessary connection the create the global market. All with its single countries also there is the supranational institutions which they have delegated monitors to continue into the healthy way to produce more and create the necessary value-added activity.

With the new trade theory which is proposed by the Paul Krugman, the world benefited from selling more with the economies of scale concept all around the world with a tremendous amount to create a considerable amount of income and share this wealth with the places they need help. Of course, all the attempts in the globalization start with the liberalization to freeing the market to remove the barriers to the nations to make the international connections among each other. There are plenty of studies such as Demirgüç-Kunt \& Detragiache (1999), Levine (2001), Kaminsky \& Schmukler (2002), Bekaert et al. (2005) and Caprio et al. (2006) that studied and provided the necessary 
pieces of evidence and the framework to study of the financial liberalisation. Mostly they connect the liberalisation with ensuring the economic growth into the countries they are previously were closed. With the attempts of the freeing the market with the liberalizations, the countries have the opportunities to create more than ever before they were closed. Such as the developing countries which they want to create the necessary value-added activities in their economy and also provide the necessary development, they needed to find the necessary capital to convert into the investment in the economy. Most of the developing countries did not have the necessary capital to provide prosperity into the economy to help their country. Therefore, for removing the restrictions on the capital flows and reaching to the necessary capital primary sources, they can borrow and use the necessary capital into the economy as an investment to develop their countries. The developing countries are usually suffering to generate the necessary income, because of the enormous incomes are coming from the research and development activities by the firms to create innovations. In this context, Bonfiglioli (2008) state that opening the financial markets through financial globalisation is crucial for the economic performance; subsequently, the overall effect of financial liberalization remains constantly positive for productivity and negligible for investment. Bonfiglioli (2008) provide empirical shreds of evidence for both de jure and de facto indicators compromise that financial integration mostly have a positive effect on productivity. Also, much empirical evidence is supporting the international financial integration and the connection with the productivity and volatility likely they are; Lane et al. (2003), Edison et al. (2002) and Kose et al. (2003).

Moreover, Kose et al. (2003) proposed evidence about the volatility, and they stated that the benefits of financial integration in terms of improving the risk-sharing and consumption-smoothing possibilities exist beyond some threshold. Also, they reported 
that after financial integration was apprised at the 1990s, the volatility of output growth has declined. Edison et al. (2002) found evidence that international financial integration can accelerate economic growth.

Based on the pieces of evidence profound into the literature, it can be easily observed that the financial integration into the globalisation context substantially improves the economic growth and productivity. First, the nations they are trying to accumulate the necessary capital to channelling them through the most profitable economic activities to create the necessary value-added activity. These activities are essential to creating the wealth of the nation and those sources are converted to the investment activity to create significant GDP growth into the economies. All the attempts to open the countries to integrate them into the international system was to improve the investment; therefore, economic growth and sharing the risk. All these opportunities were to create massive efforts by the countries first opening their countries and then integrating each other into the globalisation contexts. Also, not just for financial integration also, Europe succeeds to integrate the member countries economically into the European Union.

\section{Conclusion}

Over the past three decades, the world witnesses with huge development regarding with liberalisation, integration and these are connected with the economic growth. The most accelerated factor in the global economy is the, of course, international trade which is supported with the innovations and after all the capital allocation to the most profitable project all around the world. The last efforts by the countries to freeing the market and integrate each other provide the necessary opportunities all around the world with necessary capital allocation and the risk-sharing. All these options were delegated by the financial liberalisation and after all the integration. Therefore, with 
the troubling events that the global economy witnesses in the year 2020 supporting the solidarity of the world to combat all the unwanted events that create these episodes. Therefore, having the expected economic growth just only can be reached with the global economy which exists before the unstable episodes. All the necessary conditions can be avail until the economy turns back its fundamentals like the stable episodes that are having a tremendous growth rate. The capital allocation and accumulations are the most essential subject in the economy to channelling the necessary loanable funds into the investment activities.

All the support by the authorities and supranational authorities as stimulus programs are essential to providing the necessary spark to turn bak the well-performing time of the economy. All the crises and troubling time is concern by the authorities and the institution for guaranteeing to turn back well-functioning time in the economy. All the predicted economic growth paths are eligible until the global economy would be the same like the whole time, and the international trade and capital flow are the only profounded solutions for the countries again having the linkage to create the needed income streams from the global trade and economic activities.

\section{References}

Austin, J. (2016). What Exactly Is Market Integrity: An Analysis of One of the Core Objectives of Securities Regulation. Wm. \& Mary Bus. L. Rev., 8, 215.

Bekaert, G., Harvey, C. R., \& Lundblad, C. (2005). Does financial liberalization spur growth?. Journal of Financial economics, 77(1), 3-55.

Bonfiglioli, A. (2008). Financial integration, productivity and capital accumulation. Journal of International Economics, 76(2), 337-355. 
Caprio, G., Honohan, P., \& Stiglitz, J. E. (Eds.). (2006). Financial liberalization: how far, how fast?. Cambridge University Press.

Demirgüç-Kunt, A., \& Detragiache, E. (1999). Financial liberalization and financial fragility. The World Bank.

Edison, H. J., Levine, R., Ricci, L., \& Sløk, T. (2002). International financial integration and economic growth. Journal of international money and finance, 21(6), 749-776.

Eichengreen, B., Eichengreen, B. J., Mathieson, D. J., Jansen, A., Chadha, B., Kodres, L. E., \& Sharma, S. (1998). Hedge funds and financial market dynamics (No. 166). International Monetary Fund.

Fama, E. F. (1991). Efficient market hypothesis. The Journal of Finance, 46, 383-417. Kaminsky, G., \& Schmukler, S. (2002). Short-run pain, long-run gain: the effects of financial liberalization. The World Bank.

Kose, M. A., Prasad, E. S., \& Terrones, M. E. (2003). Financial integration and macroeconomic volatility. IMF Staff papers, 50(1), 119-142.

Krugman, P. R. (1994). Rethinking international trade. MIT press.

Lane, P. R., \& Milesi-Ferretti, G. M. (2003). International financial integration. IMF Staff Papers, 50(1), 82-113.

Levine, R. (2001). International financial liberalization and economic growth. Review of international Economics, 9(4), 688-702.

Lim, Cheng Hoon and Costa, Alejo and Columba, Francesco and Kongsamut, P and Otani, Akira and Saiyid, M. and Wezel, Torsten and Wu, Xiaoyong, Macroprudential Policy: What Instruments and How to Use Them? Lessons from Country Experiences 
(October 2011). IMF Working Papers, Vol., pp. 1-85, 2011. Available at SSRN: https://ssrn.com/abstract $=1956385$

Malkiel, B. G. (2011, October). The efficient-market hypothesis and the financial crisis. In Rethinking finance: perspectives on the crisis (Proceedings of a conference). Russel Sage Foundation.

McCauley, J. L. (2000). The futility of utility: how market dynamics marginalise Adam Smith. Physica A: Statistical Mechanics and its Applications, 285(3-4), 506-538.

Rothschild, E. (1994). Adam Smith and the invisible hand. The American Economic Review, 84(2), 319-322.

Scott, H. S. (2010). The reduction of systemic risk in the United States financial system. Harv. JL \& Pub. Pol'y, 33, 671.

Spatt, C. S. (2009). Regulatory conflict: Market integrity vs. financial stability. U. Pitt. L. Rev., 71, 625. 